\title{
Antibacterial Activity of Thespesia populnea Mediated Nanoparticles
}

\author{
A. Jayasri ${ }^{1 *}$, P. Eswara Prasad ${ }^{1}$, K. Padmaja ${ }^{2}$, B. D. P. Kala Kumar ${ }^{3}$, \\ M. Gnanaprakash ${ }^{4}$ and K. Kavitha ${ }^{5}$
}

${ }^{1}$ Department of Veterinary Biochemistry, ${ }^{3}$ Department of Veterinary Pharmacology and Toxicology, ${ }^{4}$ Department of Animal Genetics and Breeding, ${ }^{5}$ Department of Veterinary Microbiology, College of Veterinary Science, Rajendranagar, PVNRTVU, India

${ }^{2}$ Department of Veterinary Biochemistry, College of Veterinary Science, Tirupati, SVVU, India

*Corresponding author

\section{A B S T R A C T}

Keywords

Thespesia populnea, Nano particles, Silver, zinc oxide, Antibacterial, MIC

\section{Article Info}

Accepted: 10 January 2021 Available Online: 10 February 2021
Many medicinal plants have been used for centuries in daily life to treat microbial diseases all over the world. In this study, the in vitro antibacterial activity of Thespesia populnea methanolic extract (TPE), Thespesia populnea methanolic extract mediated nanosilver particles (TPNS) and Thespesia populnea methanolic extract mediated nano zinc oxide particles (TPNZ) were investigated. The results of in vitro antibacterial studies indicated highest antibacterial activity for TPNS as evidenced by lowest MIC value $(10.62 \mu \mathrm{g} / \mathrm{ml})$ when compared to TPNZ $(25 \mu \mathrm{g} / \mathrm{ml})$ and TPE $(125 \mu \mathrm{g} / \mathrm{ml})$ against Staphylococcus aureus isolated from milk sample of clinical bovine mastitis case.

\section{Introduction}

Nanotechnology is one of the most fascinating research areas in modern material science. Nanoparticles are gaining importance in the fields of biology, medicine and electronics owing to their unique physical and biological properties (Morones et al., 2005). Recent studies are focused towards synthesis of nanoparticles using plant materials like, iron, copper, calcium, gold, palladium, zinc and silver. Silver and zinc oxide has been recognised of its importance in chemistry, physics and biology due to its unique properties. Hence, among the metal nanoparticles, silver nanoparticles (AgNPs) and Zinc oxide nanoparticles (ZnONPs) synthesised from medicinal plants have received much attention for their various biological properties such as anthelmintic (Seema and Amrish 2012), antilarvicidic (Sundaravadivelan et al., 2013), antioxidant (Kumara et al., 2014), anticancer (Vasanth et al., 2014), anti-inflammatory (Rafie and 
Hamed 2014), hepatoprotective (Bhuvaneswari et al., 2014), wound healing (Seema et al., 2014) and antimicrobial (Marutikesava et al., 2014). Nano silver and nano $\mathrm{ZnO}$ particles are proven to have antibacterial (John, 2016; Aparna et al., 2018 and Panaceck et al., 2006) activity against a wide range of gram positive and gram negative organisms including multidrug resistant bacteria. In recent times, herbal mediated synthesis of nano particles compared to other methods of synthesis is drawing much attention due to its less toxicity, low cost, eco-friendly nature, controlled particle size and stability (Li et al., 2011). Thespesia populnea commonly known as Indian tulip tree, is an evergreen tree that belongs to family, Malvaceae. The leaves of $T$. populnea contain a number of bioactive constituents like flavonoids, alkaloids, phenolic compounds, saponins and steroids (Sharma et al., 2011). Further, it was reported to possess antibacterial (Krishnamoorthy et al., 2014; Shekshavali and Hugar, 2012 and Archana et al., 2010), anti-inflammatory (Ilavarasanet al., 2011 and Vasudevan et al., 2007) and antioxidant activities (Vadlapudi and Naidu, 2009; Raju et al., 2003). Both the herbal extract and nano particles together has been proved beneficial in exerting bactericidal action, reducing damage to tissues, because of their ability to penetrate deep into the cells. Hence, in this study an attempt has been made to evaluate the antimicrobial activity of TPE, TPNS and TPNZ.

\section{Materials and Methods}

\section{Collection and identification of plant material}

The leaves of Thespesia populnea were collected from in and around Tirupati in Chittor district of Andhra Pradesh. The plant was identified and authenticated by a taxonomist in the Department of Botany,
University College of Science and Arts, S.V University, Tirupati.

\section{Preparation of methanolic leaf extract}

Thespesia populnea methanolic leaf extract (TPE) was prepared by using cold maceration method. The leaves of $T$. populnea were shade dried and ground to a coarse powder. About $100 \mathrm{~g}$ of leaf powder was soaked in $500 \mathrm{ml}$ of $95 \%$ methanol (v/v) for $72 \mathrm{~h}$ with intermittent mixing using a glass rod and then filtered through muslin cloth followed by Whatman No. 1 filter paper. The filtrate was concentrated by rotary evaporator and then air dried. Extract was weighed and the percentage yield was calculated with reference to the air-dried material.

\section{Synthesis of TPE mediated nano silver particles}

Thespesia populnea solution (2\%) was prepared by dissolving $T$. populnea methanolic leaf extract in the distilled water. Silver nitrate solution $(0.1 \mathrm{M})$ was prepared and to $10 \mathrm{ml}$ of $2 \%$ TPE, $90 \mathrm{ml}$ of $0.1 \mathrm{M}$ silver nitrate solution was added at $95^{0} \mathrm{c}$ with vigorous stirring. Then change in colour of the solution was observed from pale yellow to brown which indicates the formation of TPE mediated silver nanoparticles. The prepared solution was cooled to room temperature and particles were allowed to settle for $24 \mathrm{~h}$. The solution was then changed to a plastic container for further characterization.

\section{Synthesis of TPE mediated nano ZnO (TPNZ) particles}

Zinc acetate $0.25 \mathrm{~g}$ was dissolved in $50 \mathrm{ml}$ of distilled water and $4 \mathrm{ml}$ of TPE was added drop wise and the resulting mixture was stirred for 10 minutes using magnetic stirrer, Finally the $\mathrm{PH}$ of the solution was adjusted to12, using $2 \mathrm{M} \mathrm{NaOH}$. A white crystalline 
precipitate of zinc oxide was obtained, which is washed repeatedly with water, filtered and dried in an oven at $60^{\circ} \mathrm{C}$ to obtain zinc oxide nanoparticles.

\section{Evaluation of Antibacterial activity of TPE mediated nanoparticles}

To evaluate the antibacterial activity of Thespesia populnea mediated nanoparticles, the Minimum Inhibitory Concentration was estimated using broth tube dilution method as described by Geert Huys (2002). The turbidity standard was prepared by addition of $99.5 \mathrm{ml}$ of $\mathrm{H}_{2} \mathrm{SO}_{4}(0.18 \mathrm{~mol} / \mathrm{l})$ to $0.5 \mathrm{ml}$ of $\mathrm{BaCl}_{2}$, $2 \mathrm{H}_{2} \mathrm{O} \quad(1.175 \%)$ with constant stirring to maintain a suspension. The correct density of the turbidity standard was checked by measuring the absorbance using Spectrophotometer. The absorbance at 625 $\mathrm{nm}$ should be 0.08 to 0.10 for $0.5 \mathrm{McFarland}$ standard.

Further, inoculum was prepared from $S$. aureus culture in nutrient broth followed by incubation at $37^{\circ} \mathrm{C}$ for $18 \mathrm{~h}$ and the count was standardized to $0.5 \mathrm{McFarland}$ unit. This led to the formation of a suspension containing approximately 1 to $2 \times 10^{8} \mathrm{CFU} / \mathrm{ml}$ of $S$. aureus.

Thespesia populnea extract was diluted to get a series of concentrations from $500 \mu \mathrm{g} / \mathrm{ml}$ to $31.25 \mu \mathrm{g} / \mathrm{ml}$, TPNS from $42.5 \mu \mathrm{g} / \mathrm{ml}$ to 2.65 $\mu \mathrm{g} / \mathrm{ml}$ and TPNZ from $100 \mu \mathrm{g} / \mathrm{ml}$ to 6.25 $\mu \mathrm{g} / \mathrm{ml}$. followed by addition of $5 \mathrm{ml}$ of sterile nutrient broth to all the test tubes. Around 50 $\mu \mathrm{l}$ of standardized broth culture was added to all the tubes and were incubated for $18 \mathrm{~h}$ at $37^{\circ} \mathrm{C}$. The end point was defined as the lowest concentration of the test compound at which there was no visible growth. The growth in the tubes was compared to that with positive and negative controls. Ceftriaxone was used as an antibiotic control. The lowest concentration of the test compound inhibiting the growth of the organisms is recorded as MIC.

\section{Results and Discussion}

The in vitro antibacterial activity of the test compounds was evaluated by tube dilution method against $S$. aureus isolated from bovine clinical mastitis case.

In the present study, MIC of $T$. populnea extract (TPE), TPNS and TPNZ was found to be $125 \mu \mathrm{g} / \mathrm{ml}, 10.62 \mu \mathrm{g} / \mathrm{ml}$ and $25 \mu \mathrm{g} / \mathrm{ml}$ respectively depicting higher anti-bacterial activity of TPNS followed by TPNZ when compared to TPE alone. SreeVani et al., (2016), Chaitanya et al., (2013) and Muralidhar et al., (2017) also reported the higher MIC values of phytogenic AgNPs against $S$. aureus when compared to AgNPs or herbal extract alone. Krishnamoorthy et al., (2014) observed MIC of 125 and $250 \mu \mathrm{g} / \mathrm{ml}$ against $S$. aureus MTCC 737 and 7443 strains with TPE. Das and Chakraborty et al., (2018) reported that silver nanoparticles were more potent antibacterial agents because of their lower MIC value $(3.56 \mu \mathrm{g} / \mathrm{ml})$ with respect to MIC value of $\mathrm{ZnO}$ nano particles $(400 \mu \mathrm{g} / \mathrm{ml})$ against $S$. aureus. Jones et al., (2008) reported MIC of nano $\mathrm{ZnO}$ as $80 \mu \mathrm{g} / \mathrm{ml}$ while Elumalai and Velmurugan (2015) reported MIC value of Azadirachta indica leaf extract mediated nano $\mathrm{ZnO}$ as $6.25 \mu \mathrm{g} / \mathrm{ml}$ against $S$. aureus.

A number of possible mechanisms for antibacterial actions of nano silver havebeen proposed like penetration into bacterial cell membrane by altering the permeability of cell membrane (Rai, 2009 and Lok et al., 2006), release of silver ions from AgNPs which further interact and inhibit function of sulfur containing proteins present in the bacterial membranes, bacterial DNA (Matsumura et al., 2003) and affecting the mitochondrial respiratory chain resulting in cellular death (Sondi and Salopek-Sondi, 2004) and also 
free radical induced oxidative stress due to sustained release of $\mathrm{Ag}+$ ions inside bacterial cells (Kim et al., 2007). Antibacterial activity of nano $\mathrm{ZnO}$ is due to direct contact of nanoparticles with cell walls of bacteria causing disintegration of bacterial cell integrity (Adams et al., 2006 and Zhang et al., 2007) and production of ROS which causes harm to bacteria and damage the lipids, DNA and proteins (Hirota et al., 2010; Kirkinezos, 2001 and Raghupathi et al., 2011).

\section{References}

Adams, L. K., Lyon, D. Y. and Alvarez, P.J.J. 2006. Comparative eco-toxicity of nanoscale $\mathrm{TiO} 2, \mathrm{SiO} 2$, and $\mathrm{ZnO}$ water suspensions. Water Research. 40:35273532.

Archana, M., Khan, A. and Bharat, J.W. 2010. Antibacterial potential of Thespesia populnea (Linn.) Sol. ex Corr. leaves and its corresponding callus against drug resistant isolates. Indian Journal of Natural Products and Resources. 1:444-449.

Bhuvaneswari, R., Chidambaranathan, N. and Jegatheesan, K. 2014. Hepatoprotective effect of Embilica officinalis and its silver nanoparticles against $\mathrm{CCL}_{4}$ induced hepatotoxicity in wistar albino rats. Digest J Nanomater Biostruct. 9:223-235.

Chaitanya, Kumar. T.V., Muralidhar, Y., Eswara, Prasad, P., Prasad, T.N.V.K.V. and Alpha, Raj. M. 2013. Evaluation of therapeutic potential of nanosilver particles synthesised using aloin in experimental murine mastitis model. IET Nanobiotechnol. 7:78-82.

Das, S. and Chakraborty, T. 2018. A review on green synthesis of silver nanoparticle and zinc oxide nanoparticle from different plants extract and their antibacterial activity against multi-drug resistant bacteria. Journal of
Innovations in Pharmaceutical and Biological Sciences. 5:63-73.

Elumalai, K. and Velmurugan, S. 2015. Green synthesis, characterization and antimicrobial activities of zinc oxide nanoparticles from the leaf extract of Azadirachta indica (L.). Applied Surface Science. 345: 329-336.

Geert,Huys, S.O.P. (Standard Operating Procedures). 2002. Antibiotic susceptibility testing of aquacultureassociated bacteria with the broth macrodilution method (MIC determination), Laboratory of Microbiology, Gent, Belgium.

Hirota, K., Sugimoto, M., Kato, M., Tsukagoshi, K., Tanigawa, T. and Sugimoto, H. 2010. Preparation of zinc oxide ceramics with a sustainable antibacterial activity under dark conditions. Ceram. Int. 36:497-506.

Ilavarasan, R., Mohideen, S. and Venkataraman, S. 2011.Thespesia populnealeaf extracts. Natural product Research. 11:1616-1620.

John Paul Eda 2016 Evaluation of wound healing properties of Thespesia populnea Linn mediated nano silver in wistar rats. M.V.Sc. Thesis. SVVU, Tirupati

Jones, N., Ray, B., Ranjit, K. T., Manna, A. C. 2008. Antibacterial activity of $\mathrm{ZnO}$ nanoparticle suspensions on a broad spectrum of microorganisms. FEMS Microbiol. Lett. 279:71-76.

Kim, S. J., Kuk, E., Yu, K.N., Kim, J.H., Park, S.J., Lee, H.J., Kim, S.H., Park, Y.K., Park, Y.H., Hwang, C.Y., Kim, Y.K., Lee, Y.K., Jeong, D.H. and Cho, M.H. 2007. Antimicrobial effects of silver nanoparticles. Nanomedicine. 3:95-101.

Kirkinezos, I.G. and C. T.Moraes. 2001. Reactive oxygen species and mitochondrial diseases. Seminars in cell \& developmental biology.12:449-457. 
Krishnamoorthy, S., Gnanaprakasam, Adaikala, Raj. and Manivachagam, Chandrasekaran. 2014. Antibacterial and antifungal activity of leaves of Thespesia populnea. International Journal of pharmacy and pharmaceutical sciences. 6: 404-411.

Kumara, Swamy, M., Sudipta, K.M., Jayanta, K., Balasubramanya, S. 2014. The green synthesis, characterization, and evaluation of the biological activities of silver nanoparticles synthesized from Leptadenia reticulata leaf extract. Appl Nanosci.

Li, M., Zhu, L. and Lin, D. 2011. Toxicity of $\mathrm{ZnO}$ nanoparticles to Escherichia coli: Mechanism and the influence of Medium Components. Environ. Sci. Technol. 45:1977-1983.

Lok, C.N., Ho, C.M., Chen, R., He, Q.Y., Yu, W.Y., Sun, H., Tam, P.K., Chiu, J.F. and Che, C.M. 2006. Proteomic analysis of the mode of antibacterial action of silver nanoparticles. Journal of Proteome Research. 5:916-924.

Marutikesavakumar, Ch., Yugandhar, P., Suhrulatha, D., Savithramma, N. 2014. Synthesis, characterization and antimicrobial studies of stem bark mediated synthesis of silver nanoparticles from Adansonia digitata (L.) J Pharm Sci Res.7:76-82.

Matsumura, K., Yoshikata, S., Kunisaki, S. and Tsuchido, R. 2003. Mode of bactericidal action of silver zeolite and its comparison with that of silver nitrate.Appl. Environ. Microbiol. 69: 4278-4281.

Morones, J.R., Elechiguerra, J.L., Camacho, A., Holt, K., Kouri, J.B., Ramirez, J.T., Yacaman, M.J. 2005. The bactericidal effect of silver nanoparticles. Nanotechnology. 16:2346-2353.

Muralidhar, Y., Alpha, Raj. M., Prasad, T.N.V.K.V., Chaitanya, Kumar, T.V., Adilaxmamma, K., Srilatha, C.H.,
Sreeenivasa, Rao. G., SreeVani, P. and Aparna, N. 2017. Antibacterial, antiinflammatory and antioxidant effects of acetyl- 11- $\alpha$-keto- $\beta$-boswellic acid mediated silver nanoparticles in experimental murine mastitis. IET Nanobiotechnology. 11: $682-689$.

Rafie, H.M.E. and Hamed, M.A.A. 2014. Antioxidant and anti-inflammatory activities of silver nanoparticles biosynthesized from aqueous leaves extracts of four Terminalia species. Adv Nat Sci Nanosci Nanotechnol. 5:1-11.

Raghupathi, K., Koodali, R.T. and Manna, A. 2011. Size-Dependent Bacterial Growth Inhibition and Mechanism of Antibacterial Activity of Zinc Oxide Nanoparticles. Langmuir. 27: 4020-8.

Rai, M., Yadav, A. and Gade, A. 2009. Silver nanoparticles as a new generation of antimicrobials. Biotechnol. Adv. 27:7683.

Raju, I., Mani, V., Sockalingam, A. and Subramanin, V. 2003. Antioxidant activity of Thespesia populneabark extracts against carbon tetrachlorideinduced liver injury in rats. Journal of Ethnopharmacology. 87: 227-30.

Seema, G. andAmrish, C. 2014. Bio synthesis and anthelmintic activity of silver nanoparticles using aqueous extract of Saraca indica leaves. IntJ Therapeut Appl.7:9-12.

Seema, G., Amrish, C., Avijit, M., Rupa, M. 2014. Green synthesis of silver nanoparticles using Arnebia nobilis root extract and wound healing potential of its hydrogel. Asian J Pharm. 8:95-101.

Sharma, N., Singh, N.K., Singh, O.P., Pandey, V. and Verma, P.K. 2011. Oxidative Stress and Antioxidant Status during Transition Period in Dairy Cows. Asian-Aust. J. Anim. Sci. 24: 479-484.

Shekshavali, T. and Hugar, S. 2012. Antimicrobial activity of Thespesia populnea soland. excorrea bark extracts. 
Indian Journal of Natural Products and Resources. 3:128-130.

Sondi, I. and Salopek-Sondi, B. 2004. Silver Nanoparticles as Antimicrobial Agent: A Case Study on E. coli as a Model for Gram-Negative Bacteria. Journal of Colloid and Interface Science. 275:177182.

SreeVani, P., Adilaxmamma, K., Alpha, Raj. M., Muralidhar, Y., Eswara, Prasad, P. and Prasad, T.N.V.K.V. 2016. Evaluation of the wound healing efficacy of chemical and phytogenic silver nanoparticles. IET Nanobiotechnology. 1:1-9.

Sundaravadivelan, C., Nalini, P.M., Sivaprasanth, P., Kishmu, L. 2013. Biosynthesized silver nanoparticles from Pedilanthus tithymaloides leaf extract with anti-developmental activity against larval instars of Aedes aegypti L. (Diptera; Culicidae). Parasitol Res. 112:303-311.
Vadlapudi, V. and Naidu, K.C. 2009. Evaluation of antioxidant potential of selected mangrove plants. J. Pharm. Res.2:1742-1745.

Vasanth, K., Ilango, K., Mohan, Kumar, R., Agrawal, A. and Dubey, G.P. 2014. Anticancer activity of Moringa oleifera mediated silver nanoparticles on human cervical carcinoma cells by apoptosis induction. Coll Surf B. 1:354359.

Vasudevan, M., Gunnam, K.K. and Parle, M. 2007. Antinociceptive and antiinflammatory effects of Thespesia populnea bark extract. Journal of Ethnopharmacology. 109:264-270.

Zhang, L., Jiang, Y., Ding, M. Povey. and York, D. 2007. Investigation into the antibacterial behaviour of suspensions of $\mathrm{ZnO}$ nanoparticles ( $\mathrm{ZnO}$ nanofluids). J. Nanoparticle Res. 9:479-489.

\section{How to cite this article:}

Jayasri, A., P. Eswara Prasad, K. Padmaja, B. D. P. Kala Kumar, M. Gnanaprakash and Kavitha, K. 2021. Antibacterial Activity of Thespesia populnea Mediated Nanoparticles. Int.J.Curr.Microbiol.App.Sci. 10(02): 913-918. doi: https://doi.org/10.20546/ijcmas.2021.1002.107 